\begin{tabular}{|c|c|c|}
\hline $\begin{array}{l}\text { OPEN ACCESS } \\
\text { Vol. } 4 \text { No. 1: 1-11 } \\
\text { Tahun } 2020 \\
\text { Artikel penelitian 脰 }\end{array}$ & $\begin{array}{l}\text { Eurmal Alewatilklestari } \\
\text { E-ISSN: 2598-8204 } \\
\text { http://ojs.umrah.ac.id/index.php/akuatiklestari } \\
\text { DOI: https://doi.org/10.31629/akuatiklestari.v4i1.2467 }\end{array}$ & $Q=$ \\
\hline
\end{tabular}

\title{
Kelimpahan dan Karakteristik Kepiting Bakau pada Ekosistem Mangrove di Desa Busung Kabupaten Bintan Provinsi Kepulauan Riau
}

\author{
Abundance and Characteristics of Mangrove Crab in Mangrove Ecosystem in Village Busung \\ Regency of Bintan Province Riau Islands
}

Ruli Saputra ${ }^{1}$, Aditya Hikmat Nugraha ${ }^{\circledR}$, Susiana ${ }^{2}$

IIlmu Kelautan, Fakultas Ilmu Kelautan dan Perikanan, Universitas Maritim Raja Ali Haji, Tanjungpinang, Indonesia 29111 ${ }^{2}$ Manajemen Sumberdaya Perairan, Fakultas Ilmu Kelautan dan Perikanan, Universitas Maritim Raja Ali Haji, Tanjungpinang, Indonesia 29111

\section{$\square$ Info Artikel:}

Diterima: 17 Agustus 2020

Revisi: 28 September 2020

Disetujui: 8 Oktober 2020

Dipublikasi: 30 November 2020

\section{[Deyword:}

Bintan, kepiting, mangrove, Scylla paramamosain, Scylla serrata

$\triangle$ Penulis Korespondensi: Aditya Hikmat Nugraha

Program Studi Ilmu Kelautan, Fakultas IImu Kelautan dan Perikanan, Universitas Maritim Raja Ali Haji, Tanjungpinang, Indonesia 29111

Email: adityahn@umrah.ac.id

\begin{abstract}
ABSTRAK. Penelitian ini mengenai kelimpahan dan karakteristik kepiting bakau pada ekosistem mangrove di Desa Busung Kabupaten Bintan Provinsi Kepulauan Riau. Tujuan penelitian ini adalah untuk melihat keterkaitan ekosistem mangrove terhadap kelimpahan dan karakteristik kepiting bakau di Desa Busung Kecamatan Sri Kuala Lobam Kabupaten Bintan. Penelitian ini dilakukan den, gan metode purposive sampling sebanyak 9 titik menggunakan transek garis berukuran $10 \times 10$ meter. Hasil yang diperoleh yaitu 2 jenis vegetasi mangrove Rhizopora apiculata dan Xylocarpus granatum. Nilai kerapatan pohon vegetasi mangrove jenis Rhizopora apiculata pada stasiun satu berjumlah 700 pohon/ha dan jenis Xylocarpus granatum berjumlah 1100 pohon/ha, pada lokasi penelitian stasiun dua vegetasi pohon mangrove jenis Rhizopora apiculata berjumlah 700 pohon/ha dan jenis Xylocarpus granatum berjumlah 900 pohon/ha, sedangkan pada lokasi penelitian stasiun tiga vegetasi pohon mangrove jenis Rhizopora apiculata berjumlah 1233 pohon/ha dan jenis Xylocarpus granatum berjumlah 300 pohon/ha. Kepiting bakau yang dijumpai pada lokasi penelitian yaitu jenis Scylla serrata dan Scylla paramamosain, jenis Scylla serrata ditemukan berjumlah 5 ekor sedangkan Scylla paramamosaian 18 ekor dengan jenis kelamin yang paling dominan jantan.
\end{abstract}

\begin{abstract}
This research on the abundance and characteristics of mangrove crab on mangrove ecosystem in Busung Village, Bintan Island, Riau Islands Province. The purpose of this study was to see the relation between of the mangrove ecosystem to the abundance and characteristics of mangrove crab in Busung Village subdistrict of Sri Kuala Lobam regency of Bintan. This research has done by purposive sampling As many as 9 dots used transect line measured 10x10 meters. The result have 2 types of mangrove vegetation Rhizopora apiculata and Xylocarpus granatum. Density value of mangrove vegetation species Rhizopora apiculata At one station amounted to 700 trees/ha and the type Xylocarpus granatum Number 1100 trees/ha, at the site of research station two vegetation mangrove species Rhizopora apiculata Numbering 700 trees/ha and type Xylocarpus granatum amounted to 900 trees/ha, While on the site was research stations are Three vegetation mangrove have tree type Rhizopora Apiculata amounted to 1233 trees/ha and type Xylocarpus granatum numbering 300 trees/ha. Mangrove crabs has found at the research site, namely Scylla serrata and Scylla paramamosain, spesies Scylla serrat Found 5 tails while Scylla paramamosaian 18 tails with most dominant male
\end{abstract}

篔 How to cite this article:

Saputra, R., Nugraha, A.H., \& Susiana. (2020). Kelimpahan dan Karakteristik Kepiting Bakau pada Ekosistem Mangrove di Desa Busung Kabupaten Bintan Provinsi Kepulauan Riau. Jurnal Akuatiklestari, 4(1): 1-11. https://doi.org/10.31629/akuatiklestari.v4i1.2467

\section{PENDAHULUAN}

Mangrove adalah suatu vegetasi pantai yang memiliki karakteristik tertentu yang umumnya bisa dijumpai di daerah pantai, estuari, muara sungai dan delta. Ekosistem mangrove merupakan ekosistem yang menjadi perbatasan antara darat dengan laut. Ekosistem mangrove juga sering dinamakan hutan pantai, hutan pasang surut, hutan payau atau hutan bakau (Fitriah et al., 2013). Menurut Julaikha \& Sumiyati (2017) ekosistem mangrove memiliki sifat yang kompleks dan dinamis, dikatakan kompleks dikarenakan ekosistem mangrove merupakan habitat satwa dan biota perairan yang jenisnya sedangkan secara dinamis, bentuk maupun wujud dari ekosistem mangrove sangat beragam dan bervariasi di lingkungannya. 
Menurut Setiawan (2013), ekosistem mangrove memiliki fungsi ekologis sebagai tempat mencari makan, memijah dan berkembang biak bagi biota lain. Salah satu biota yang memanfaatkan ekologis hutan mangrove ialah kepiting bakau. Kepiting bakau dapat dijumpai pada setiap perairan pantai yang banyak ditumbuhi oleh vegetasi mangrove. Hutan mangrove bagi kepiting memiliki fungsi yang sangat bermakna bagi kelangsungan hidup mereka dalam bertahan hidup (Irwani \& Suryono, 2012).

Keberadaan kepiting bakau sangat dipengaruhi oleh kondisi ekosistem mangrove yang ada di sekitarnya. Secara umum pakan alami kepiting adalah serasah dari pohon, daun, dan buah mangrove yang dimana masih banyak terdapat di kawasan perairan Desa Busung (Unthari et al., 2018).

Desa Busung yang berada di Kecamatan Seri Kuala Lobam Kabupaten Bintan merupakan desa yang memiliki daerah pantai yang luas serta memiliki ekosistem mangrove yang masih cukup banyak (Setiawan, 2015). Masyarakat Desa ini mayoritas mata pencariannya sebagai nelayan dengan salah satu komoditas tangkapan adalah kepiting bakau. Keberadaan kepiting bakau tentunya memiliki nilai ekonomis di wilayah tersebut. Penelitian ini akan membandingkan kelimpahan dan karakteristik kepiting bakau pada ekosistem mangrove di Desa Busung, Kabupaten Bintan, Provinsi Kepuluan Riau. Tujuan penelitian ini ialah untuk mengstimasi kelimpahan dan karakteristik kepiting bakau pada ekosistem mangrove dengan kerapatan pohon mangrove yang berbeda di Desa Busung Kecamatan Sri Kuala Lobam Kabupaten Bintan.

\section{BAHAN DAN METODE}

\section{2.l. Waktu dan Tempat}

Penelitian ini dilaksanakan pada bulan April 2020 sampai Mei 2020 di perairan Desa Busung Kecamatan Sri Kuala Lobam berikut peta lokasi disajikan pada Gambar 1.

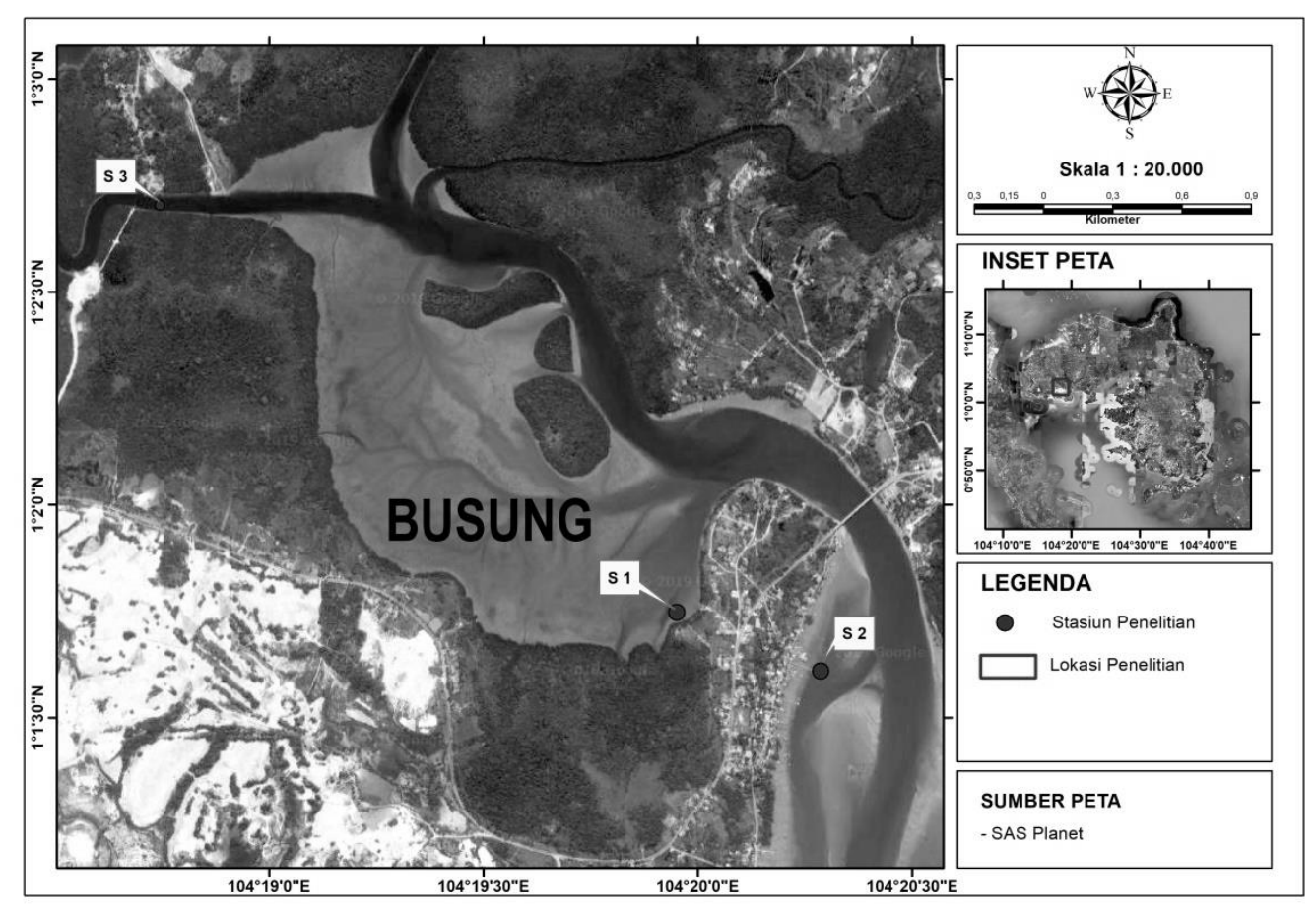

Gambar 1. Peta Lokasi Penelitian

\subsection{Alat dan Bahan}

Alat dan bahan yang digunakan dalam penelitian ini ialah Roll meter menentukan panjang stasiun, tali rafia menghitung kerapatan pohon mangrove, oven mengeringkna substrat, buku identifikasi kepiting untuk mengetahui jenis kepiting, kamera dokumentasi, alat tulis mencatat data, Aquades menseterilkan alat, GPS (Global positoning system) merekam titik koordinat, bubu kepiting, Hand rafraktometer mengukur salinitas perairan, Multitester mengukur parameter $\mathrm{pH}$ dan suhu, Cool box menyimpan sampel, jangka sorong mengukur karapas kepiting, timbangan analitik mengukur bobot kepiting, pipa paralon mengambil sampel substrat, Microsoft excel perangkat lunak untuk mengolah data dan menyimpan data, Arc map 10.2 perangkat lunak membuat lokasi penelitian.

\subsection{Prosedur Penelitian}

Prosedur penelitian ini dilaksanakan beberapa tahapan atau langkah kerja yang disusun secara sistematis dan disajikan pada Gambar 2. 


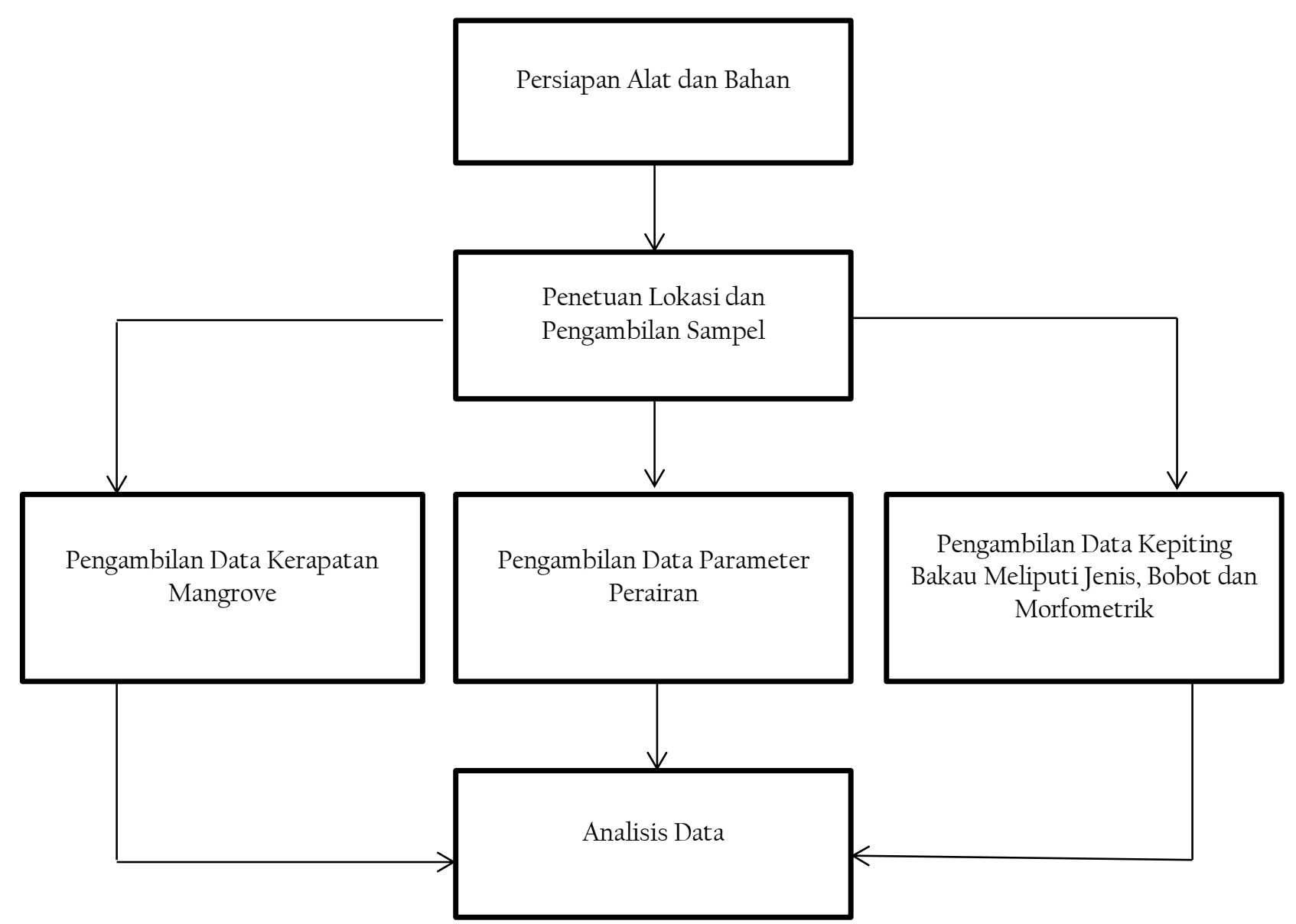

Gambar 2. Skema Prosedur Langkah Penelitian

\subsection{Teknik Pengumpulan Data}

Pengukuran data mangrove dilakukan dengan metode transek garis dan petak atau Line Transect point metode Line Transect Point adalah metode ini berdasarkan keputusan Menteri Lingkungan Hidup No. 201 Tahun (2004), dengan menetapkan setiap transek garis dari arah laut ke arah darat. Metode pengukuran ini merupakan salah satu metode pengukuran paling mudah dilakukan, namun memiliki tingkat akurasi dan ketelitian yang akurat. Kategori tegakan mangrove yang di ukur yaitu kategori jenis pohon yang mana berikut Gambar 3 ilustrasi transek garis

\section{LAUT}

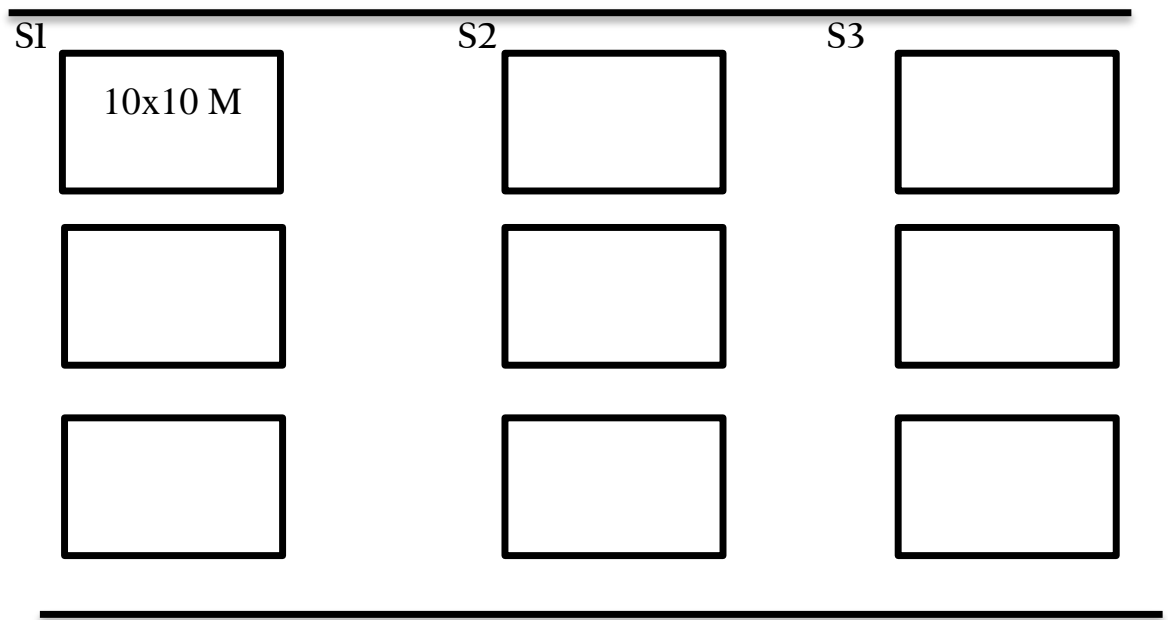

Gambar 3. Skema Pengambilan Data Mangrove

\subsubsection{Proses Pengambilan Data Kepiting}

Pengamatan kepiting menggunakan metode observasi visual atau secara langsung (Zakaria \& Rajpar, 2015). Pengambilan data kepiting ini dilakukan dengan alat tangkap kepiting secara tradisional pada setiap 3 stasiun mangrove dengan kategori jenis kerapatan pohon mangrove yang berbeda yaitu: Ekowisata Mangrove, Pesisir Pantai, 
Pemukiman Masyarakat. Perangkap kepiting bakau di letakkan di dalam transek mangrove dalam petakan yang berukuran lxl m dengan jumlah seluruh perangkap sebanyak 15 bubu, dimana setiap petakan mangrove diletakkan 5 bubu dengan 3 kali pengulangan pengambilan data. Posisi alat tangkap kepiting selalu berubah-ubah sehingga mampu menempati seluruh petakan pengamatan. Berikut merupakan ilustrasi pengambilan data kepiting bakau pada Gambar 4.

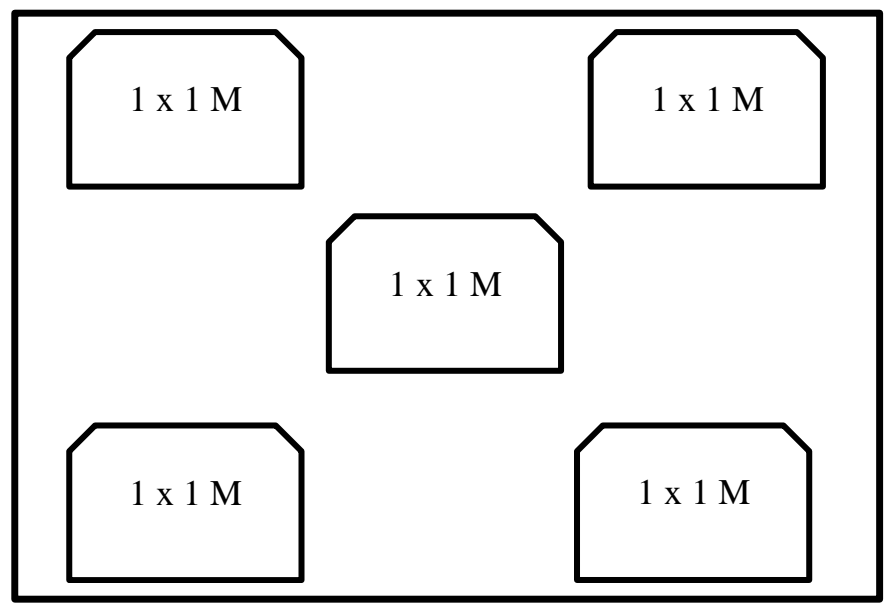

Gambar 4. Skema Pengambilan Data Kepiting Bakau

\subsubsection{Pengukuran Morfometrik Kepiting Bakau}

Pengukuran morfometrik pada kepiting bakau meliputi bagian tubuh kepiting pada Gambar 5 panjang kerapas (PK) yaitu jarak dari lekuk dahi bagian tengah sampai batas abdomen bagian dorsal. Lebar kerapas (LK), yaitu dari ujung duri terakhir anterolateral sebelah kanan sampai ujung duri terakhir sebelah kiri. Panjang kaki renang (PKR), yaitu jarak dari batas antara propundus dengan daktilus kaki renang sampai bagian ujung daktilus kaki renang. Lebar kaki renang (LKR) yaitu jarak dari tepi atas bagian tengah daktilus kaki renang sampai tepi bawah bagian kaki renang. Duri kerapas (DK) mengamati bentuk duri yang terdapat pada lingkaran kerapas. Duri carpus (DC), yaitu mengamati ada apa tidak duri yang terdapat pada carpus, adapun pengukuran mofometrik pada kepiting bakau menggunakan alat jangka sorong.

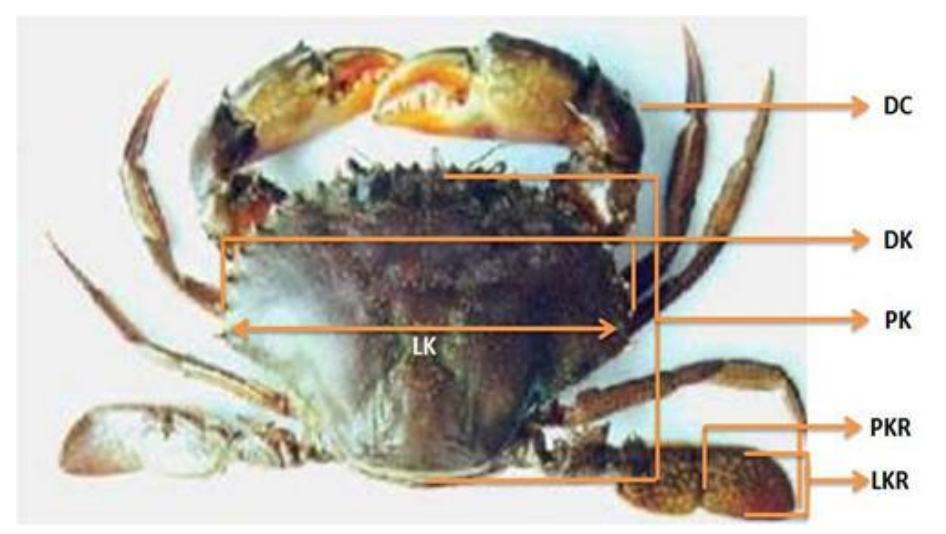

Gambar 5. Skema Pengukuran Morfometrik Kepiting Bakau

\subsubsection{Proses Pengambilan Data Parameter Perairan}

Pengambilan parameter perairan merupakan bagian dari data pendukung untuk menentukan kualitas perairan di Desa Busung. Parameter yang diukur meliputi salinitas, suhu, substrat, $\mathrm{pH}$ dan DO perairan, pengukuran salinitas menggunakan Hand rafraktometer. Pengukuran DO, suhu, dan $\mathrm{pH}$ dilakukan dengan menggunakan alat Multitester Pengambilan substrat dilakukan dengan cara di sekop lalu disimpan ke dalam plastik sampel dan disimpan ke cool box.

\subsection{Analsis Data}

\subsubsection{Kerapatan Mangrove}

Kerapatan mangrove dihitung dengan menggunakan persamaan berikut (Buwono, 2017) :

$$
\mathrm{K}=\frac{\text { Jumlah induvidu }}{\text { Luas seluruh petakan }}
$$


Dengan demikian, densitas ke-i dapat dihitung sebagai $\mathrm{K}-\mathrm{i}$ dan densitas relative setiap spesies ke-i terhadap kerapatan total dapat dihitung sebagai KR-i.

$$
\begin{aligned}
& \mathrm{ki}=\frac{\text { Jumlah induvidu untuk spesies ke } i}{\text { Luas seluruh petakan }} \\
& \mathrm{KR} i=\frac{\text { Kerapatan spesies ke } \mathrm{i}}{\text { Kerapatan seluruh spesies }} \times 100 \%
\end{aligned}
$$

Keterangan :

$\begin{array}{ll}\mathrm{K} & =\text { merupakan kerapatan }(\text { pohon } / \mathrm{ha}), \\ \mathrm{K}-\mathrm{I} & =\text { merupakan kerapatan spesies ke-i }(\text { pohon/ha) } \\ \mathrm{KR}-\mathrm{i} & =\text { merupakan Kerapatan relatif spesies ke-i }(\%) .\end{array}$

2.5.2. Kelimpahan Kepiting Bakau

Menurut Siringoringo et al. (2017), untuk mengetahui kelimpahan kepiting bakau menggunakan rumus sebagai berikut:

$$
\mathrm{N}=\frac{\sum \mathrm{ni}}{\mathrm{A}}
$$

Keterangan :

$\mathrm{N} \quad=$ merupakan kelimpahan kepiting bakau jenis I (ind/ha),

$\sum$ ni = merupakan jumlah induvidu jenis i,

$\mathrm{A}=$ merupakan luas daerah pengamatan $\operatorname{contoh}(\mathrm{ha})$.

\subsection{Analisis Statistik}

Analisis statistik yang digunakan dalam penelitian ini menggunakan acuan Principal Component Analysis, untuk mengetahui hubungan antara mangrove, kepiting bakau dan parameter kualitas perairan. Menurut Chadijah et al. (2013), hasil analisis statistik menggunakan acuan Principal Component Analysis atau bisa disebut PCA berpedoman pada (Bengen, 2000). Analisi PCA ini merupakan metode statistik interpenden yang bertujuan mempersentasikan informasi maksimum yang terdapat dalam suatu matriks data dalam bentuk grafik. Untuk dapat mengetahui kelimpahan dan karakteristik kepiting bakau pada ekosistem mangrove menggunakan analisis statistik Correspondence Analysis (CA) adalah metode statistik deskriptif yang dimaksud untuk mengelompokkan unit-unit statistik kedalam kelompokkelompok homogen dari sejumlah variabel (Bengen, 2012).

\section{HASIL DAN PEMBAHASAN}

\subsection{Karakteristik Lingkungan pada Wilayah Penelitian}

Kualitas suatu perairan yang baik sangat menunjang keberlangsungan hidup suatu organisme yang berada di dalamnya Hamuna et al. (2018). Adapun parameter perairan pada ekosistem mangrove di Desa Busung disajikan pada Tabel 1 .

Tabel 1. Parameter Perairan di Desa Busung

\begin{tabular}{ccccc} 
Parameter Perairan & Stasiun I & $\begin{array}{c}\text { Stasiun Pengamatan } \\
\text { Stasiun II }\end{array}$ & Stasiun III & Baku Mutu \\
Suhu $\left({ }^{\circ} \mathrm{C}\right)$ & 32 & 32 & 32 & $28-32$ \\
Salinitas $(0 \% 0)$ & 29 & 16 & 30 & 34 \\
pH & 8,62 & 7,91 & 8,62 & $7-8.5$ \\
DO (Mg/L) & 7,2 & 3,3 & 7,7 & $>5$ \\
Kerikil (\%) & 31,41 & 61,93 & 61,27 & - \\
Pasir (\%) & 57,38 & 6,76 & 5,53 & - \\
Lumpur (\%) & 11,17 & & & - \\
\hline
\end{tabular}

Menurut Hastuti et al. (2019), suhu sangat berperan penting bagi organisme hidup sehingga mempengaruhi aktivitas, nafsu makan, konsumsi oksigen, dan laju metabolisme. Hasil pengamatan menunjukan suhu perairan di Desa Busung berkisan rata-rata $32^{\circ} \mathrm{C}$ di setiap lokasi penelitian. Menurut Keputusan Menteri Lingkungan Hidup No. 51 2004 kisaran suhu yang optimal untuk biota laut pada mangrove adalah $28-32^{\circ} \mathrm{C}$. Menurut Patty (2013), nilai salinitas di perairan laut sangat berperan penting antara lain interakasi masuknya air tawar kedalam perairan laut melalui sungai, juga dipengaruhi curah hujan, menurut keputusan menteri lingkungan hidup No.51 2004 salinitas yang baik yaitu $\leq 34$ psu. Nilai pH pada lokasi penelitian yang berada di Desa Busung setiap stasiunnya berkisar antara 7,91-8,62. Nilai pH tertinggi terdapat pada stasiun 1 dan 3 sebesar 8,62. Oksigen terlarut pada lokasi penelitian yang berada di Desa Busung pada setiap stasiun memiliki kisaran antara 7.02-7.07. Menurut Sofarini (2012), oksigen ialah suatu komponen yang paling penting di perairan. Substrat yang berada di stasiun satu dengan persentase kerikil 31,41\%, pasir 
57,38\%, dan lumpur 11,17\%. Pada stasiun dua dengan persentase kerikil 31,29\%, pasir 61,93\%, dan lumpur 6,76\%. Pada stasiun tiga substrat yang ditemui kerikil 29,27\%, pasir 61,15\%, dan lumpur 5,53\%.

\subsection{Kerapatan Mangrove}

Hasil pengamatan dan identifikasi vegetasi mangrove pada 3 stasiun pengamatan di Perairan Desa Busung disajikan pada Gambar 6 pengamatan vegetasi mangrove dilakukan pada jenis pohon (diameter $>4 \mathrm{~cm}$ ). Berdasarkan Gambar 6 vegetasi pohon mangrove pada Desa Busung di stasiun satu jenis Rhizopora apiculata berjumlah 700 pohon/ha dan jenis Xylocarpus granatum berjumlah 1100 , pada lokasi penelitian stasiun dua terdiri dari vegetasi pohon mangrove jenis Rhizopora apiculata berjumlah 700 pohon/ha dan jenis Xylocarpus granatum berjumlah 900 pohon/ha. Stasiun tiga terdapat vegetasi pohon mangrove jenis Rhizopora apiculata berjumlah 1233 dan jenis Xylocarpus granatum berjumlah 300. Mengacu kepada Keputusan Menteri Lingkungan Hidup No.201 tahun 2004, ekosistem mangrove dengan kepadatan >1500 ind/ha dikategorikan sangat padat, berdasarkan hal tersebut maka kondisi ekosistem mangrove pada seluruh stasiun penelitian berada dalam kondisi sangat padat Berdasarkan hasil penelitian di lapangan jenis vegetasi mangrove yang paling dominan yaitu mangrove jenis Rhizopora apiculata.

Menurut Hadi et al. (2016), mangrove jenis tersebut merupakan salah satu tumbuhan yang paling banyak dijumpai pada pesisir pantai. Mangrove tersebut dapat tumbuh mencapai 30 meter dengan diameter pohon $50 \mathrm{~cm}$, selain itu mangrove jenis ini juga dapat beradaptasi dengan baik terhadap substrat berpasir yang lebih keras, serta jarang ditemukan di daerah dengan pengaruh pasang surut rendah. Menurut Umroh (2015) fraksi pasir yang tinggi bisa menyebabkan mangrove jenis Rhizopora apiculata tumbuh dengan cepat di pesisir pantai.

Selain jenis mangrove Rhizopora apiculata terdapat pula rendahnya jenis mangrove $\chi$ ylocarpus granatum disebabkan tingkat eksploitasi yang berlebihan yaitu, dimanfaatkan untuk pembuatan tiang pelabuhan perikanan tangkaps dan kebutuhan pokok lainnya. Hal tersebut mengakibatkan jenis mangrove $\chi_{y}$ locarpus granatum di alam semakin berkurang dan lambat peretumbuhannya (Schaduw, 2015). Menurut Tahmid et al. (2015) struktur kerapatan vegetasi mangrove di Teluk Bintan rata-rata dalam kondisi sedang yaitu didominasi dengan jenis Rhizopora apiculata.

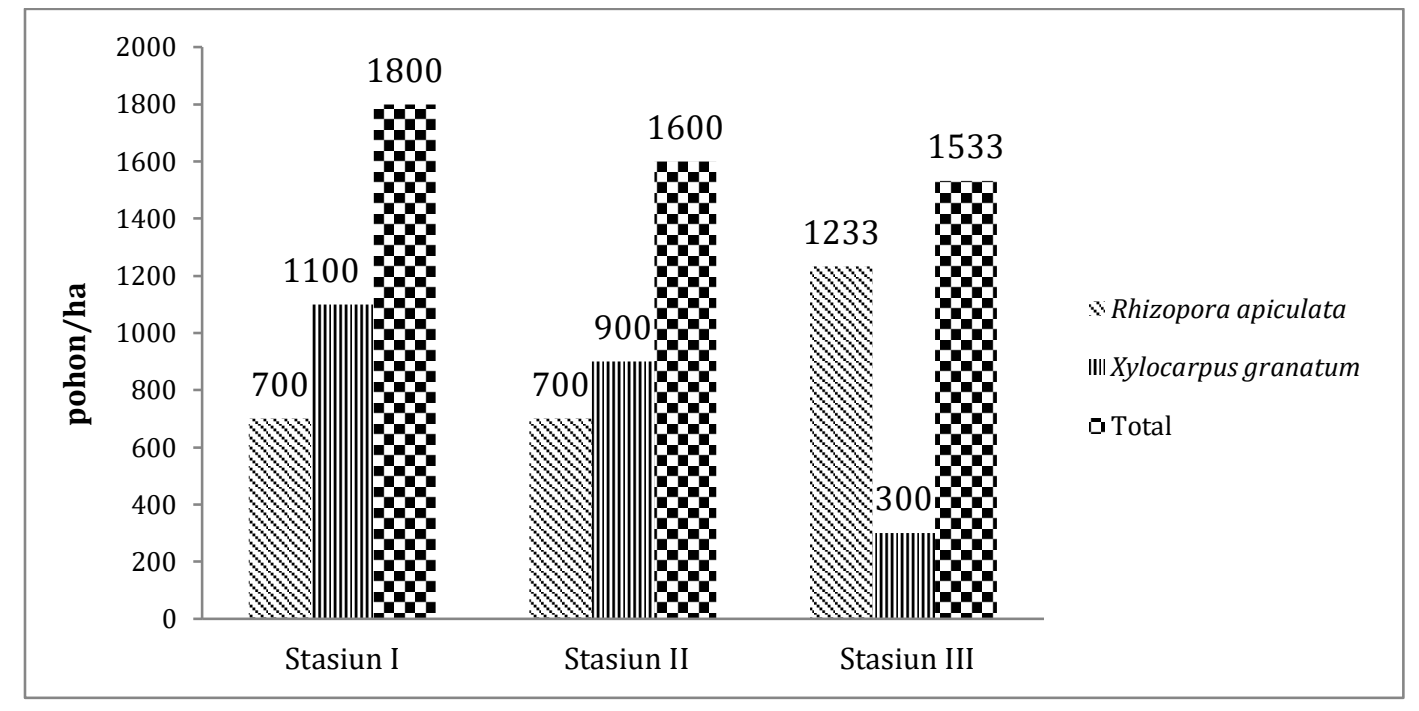

Gambar 6. Kerapatan Mangrove

\subsection{Kelimpahan Kepiting Bakau}

Kelimpahan kepiting bakau pada lokasi penelitian di Desa Busung diambil selama 40 hari dengan ukuran transek 10 x $10 \mathrm{~m}^{2}$ sebanyak 3 transek pada setiap stasiun disajikan pada Tabel 2.

Tabel 2. Kelimpahan Kepiting Bakau di Desa Busung

\begin{tabular}{clccc} 
Lokasi Penelitian & \multicolumn{1}{c}{ Jenis Kepiting Bakau } & \multicolumn{2}{c}{ Jenis Kelamin } & Total \\
& Scylla serrata & 4 & Betina & 5 \\
Stasiun 1 & Scylla paramamosain & 2 & 3 & 5 \\
Stasiun 2 & Scylla paramamosain & 1 & 2 & 3 \\
Stasiun 3 & Scylla paramamosain & 6 & 4 & 10 \\
\hline
\end{tabular}

Berdasarkan Tabel 2 kelimpahan kepiting bakau yang ditemui pada stasiun satu berjumlah total 5 jenis Scylla serrata yang terdiri dari 4 jenis jantan dan 1 jenis betina, sedangkan kepiting bakau jenis Scylla paramamosain berjumlah total 5 terdiri dari 2 jantan dan 3 betina. Kelimpahan kepiting bakau di alam sangat bergantung terhadap kesetabilan ekosistem sehingga dapat menjamin keberlangsungan hidup kepiting Syahrera et al. (2016). Pada lokasi stasiun dua 
tepatnya di pesisir pantai yang berada di Desa Busung, kelimpahan kepiting bakau yang ditemui terdiri dari jenis Scylla paramamosain yang berjumlah total 3 dengan jenis kelamin 1 jantan 1 dan 2 betina.

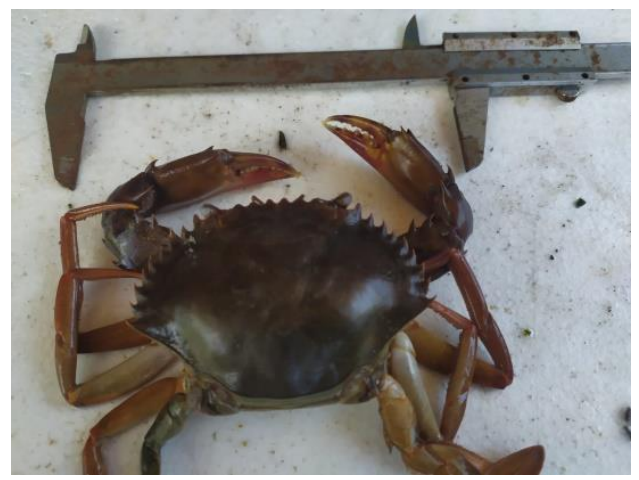

Scylla serrata

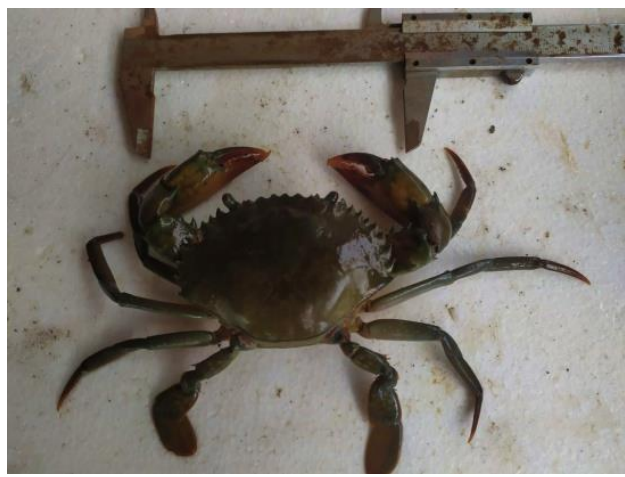

Scyllaparamamosain

Gambar 7. Jenis Kepiting Bakau Scylla serrata dan Scylla paramamosain

Pada lokasi penelitian stasiun tiga tepatnya di pemukiman masyarakat ditemui kepiting jantan paling dominan, dengan jumlah 6 jenis Scylla paramamosain. Menurut Sentosa et al. (2011), kepiting bakau jantan paling cepat pertumbuhannya dikarenakan sifat kepiting bakau yang agresif dan memerlukan energi lebih banyak dari pada betina untuk melakukan pertumbuhan.

Menurut Avianto et al. (2013), karakteristik Scylla serrata bervariasi dari ungu sampai hijau dan coklat kehitaman, dua duri tajam terdapat pada propondorus dan dua duri tajam pada carpus, duri lebar, tinggi dan agak tumpul, berbentuk segitiga. Kepiting bakau jenis Scylla paramamosaian umumnya mempunyai 6 duri mata yang berbentuk segitiga sedangkan pada carpus duri nampak kecil bahkan tidak terlihat Gambar 8. Scylla paramamosain suka terhadap substrat yang lunak ini memudahkan kepiting membuat lubang sebagai tempat istirahat dan tempat berlindung saat melakukan molting (Sunarto, 2015).

Menurut Saputri dan Muammar (2018), kepiting bakau memiliki kebiasaan hidup menetap. Hal ini disebabkan ketersediaan makan dan kenyamanan serta keberlangsungan berkembang biak dapat terjaga atau pun terlindung dari predator lainnya. Berdasarkan penelitian yang pernah dilakukan pada bulan Februari - Maret tahun 2019 di kawasan hutan bakau pasar Banggi Rembang, keanekaragaman kepiting bakau scylla spp sangat dipengaruhi oleh faktor habitat , stabilitas lingkungan, produktifitas, kompetisi dan penyangga rantai makanan (Pambudi et al., 2019).

Berdasarkan penelitian Putra et al. (2016), kelimpahan kepiting bakau jenis Scylla serrata yang paling rendah terdapat di kawasan rehabilitasi mangrove Pulo Sarok Kecamatan Singkil Kabupaten Aceh Singkil yaitu dengan nilai kelimpaham $7 \mathrm{ind} / \mathrm{m}^{2}$, adapun salah satu faktor penurunan kelimpahan kepiting bakau yaitu penangkapan berlebihan dari alam, perubahan iklim dan kurangnya intervensi pengelolaan serta kurangnya pengetahuan atau keterampilan yang dimiliki oleh nelayan dalam mengeksploitasi sumberdaya kepiting bakau. Berdasarkan penelitian Unthari et al. (2018), hubungan kerapatan mangrove terhadap kelimpahan kepiting bakau Scylla sp. di Sungai Bungin Kabupaten Banyuasin, Provinsi Sumatera Selatan menyatakan bahwa kelimpahan kepiting bakau tertinggi terdapat di stasiun satu dengan nilai kelimpahan rata-rata sebesar $675 \mathrm{ind} / 100 \mathrm{~m}^{2}$. Adapun faktor yang mendukung kelimpahan kepiting bakau jenis Scylla serrata di stasiun satu yaitu kerapatan vegetasi mangrove 900 ind/ha yang berada pada kategori sedang.

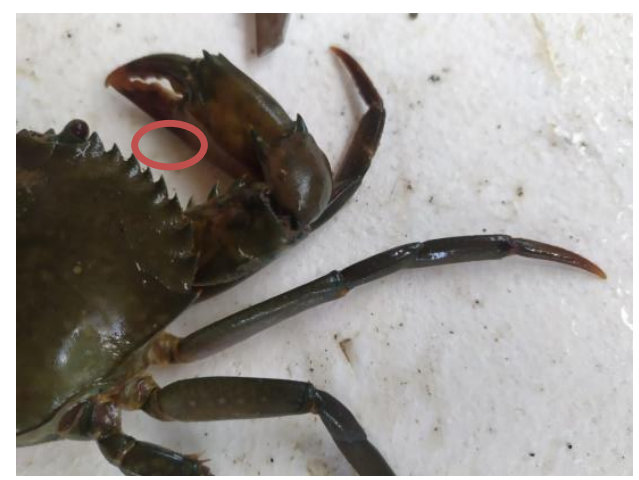

Scylla paramamosain

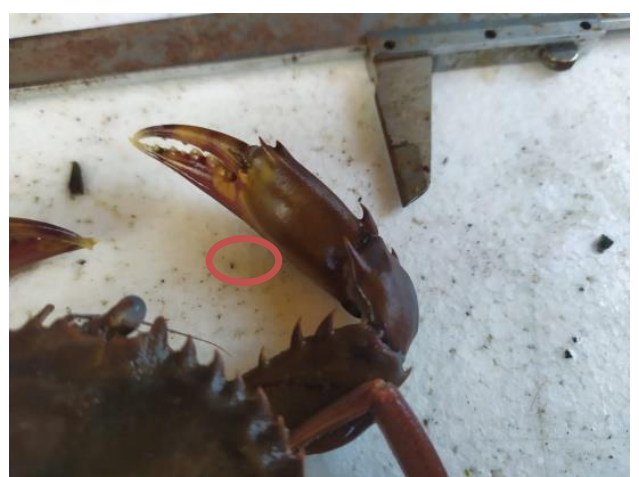

Scylla serrata

Gambar 8. Ciri-Ciri Kepiting Bakau Scylla paramamosain dan Scylla serrata 


\subsection{Karakteristik Morfometrik Kepiting Bakau}

Morfometrik ialah suatu metode pengukuran bentuk tubuh luar dijadikan sebagai bandingan ukuran makhluk hidup tertentu seperti lebar, panjang standar, tinggi badan, dan lain-lain. Tujuan lain dari pengukuruan morfometrik yaitu untuk mengetahui pola pertumbuhan, kebiasaan makan, dan golongan spesies yang akan diidentifikasi (Suryana et al., 2015). Adapun morfometrik kepiting bakau di Desa Busung disajikan pada Tabel 3. Perbedaan kisaran nilai morfometrik pada kepiting bakau dapat pada Tabel 5 kisaran morfometrik Scylla serrata meliputi panjang duri karapas (DK) 7,42 cm, panjang kerapas (PK) 5,48 cm, panjang kaki renang (PKR) $1,48 \mathrm{~cm}$, lebar kaki renang (LKR) $1,04 \mathrm{~cm}$, lebar karapas (LK) 6,92 cm, bobot 80,02 gram. Morfometrik kepiting bakau jenis Scylla paramomasain paling besar terdapat pada stasiun tiga, dengan nilai morfometrik duri karapas (DK) $5,2 \mathrm{~cm}$, panjang karapas (PK) 3,93 cm, panjang kaki renang (PKR) 0,93 cm, lebar kaki renang 0,63 cm, lebar karapas (LK) 5,27 cm dan bobot 60 gram. Menurut Wijaya et al. (2010), kategori kepiting bakau fase dewasa memiliki lebar karapas $>100 \mathrm{~mm}$.

Tabel 3. Karakteristik Morfometrik Kepiting Bakau

\begin{tabular}{cccccccc} 
Stasiun & $\begin{array}{c}\text { Jenis Kepiting } \\
\text { Bakau }\end{array}$ & DK (Cm) & PK & PKR & LKR & LK & Bobot \\
& & & $\mathbf{( C m )}$ & $\mathbf{( C m )}$ & $\mathbf{( C m )}$ & (Cm) & (gr) \\
Stasiun I & Scylla serrata & $7.42 \pm 1.26$ & $5.48 \pm 1.02$ & $1.48 \pm 0.54$ & $1.04 \pm 0.38$ & $6.92 \pm 0.93$ & $80.02 \pm 57.41$ \\
& S. paramamosain & $5.12 \pm 0.89$ & $3.48 \pm 0.59$ & $1.14 \pm 0.25$ & $0.56 \pm 0.13$ & $5.1 \pm 0.87$ & $36.06 \pm 14.77$ \\
Stasiun II & S. paramamosain & $5.25 \pm 0.75$ & $3.65 \pm 0.52$ & $1.07 \pm 0.36$ & $0.58 \pm 0.21$ & $5.2 \pm 0.80$ & $37.03 \pm 17.83$ \\
Stasiun III & S. paramamosain & $5.02 \pm 0.46$ & $3.93 \pm 1.10$ & $0.93 \pm 0.32$ & $0.63 \pm 0.15$ & $5.27 \pm 0.35$ & $60 \pm 51.64$ \\
\hline
\end{tabular}

Berdasarkan penelitian Safitri et al. (2020), di perairan Bandengan Kendal ukuran lebar kerapas dan bobot tubuh kepiting bakau tergolong kepiting bakau remaja dan muda dengan nilai rata-rata 44.5 - $54.25 \mathrm{~mm}$. Berdasarkan penelitian Tahmid (2016) kepiting bakau Scylla serrata di ekosisitem mangrove Teluk Bintan memiliki nilai rata-rata kerapas $122 \mathrm{~mm}$, berdasarkan ukuran fase tersebut kepiting bakau dilokasi Teluk Bintan sudah memasuki fase dewasa. Menurut Hardiyanti et al. (2018), faktor reproduksi yang berlangsung sepanjang tahun dan musim hujan mengakibatkan lebar karapas dan berat bervariasi. Lebar kerapas pada kepiting juga menetukan fase kehidupan. Menurut Sara (2010), kepiting bakau memiliki tiga fase kehidupan yaitu juvenil, muda dan dewasa yang dapat diketahui dari ukuran lebar karapas dimana juvenil berukuran $<70 \mathrm{~mm}, 70-<120 \mathrm{~mm}$ merupakan fase muda dan > 120 $\mathrm{mm}$ untuk fase dewasa. Berdsarakan ukuran lebar karapas kepiting bakau di lokasi penelitian, bahwa kepiting bakau dapat dikategorikan juvenil dimana rata-rata nilai karapas berada pada kisaran 5.1- $6.92 \mathrm{~cm}$. Peraturan Menteri Kelautan dan Perikanan Republik Indonesia Nomor 56/Permen-Kp/2016 pasal 3 mengatakan bahwa kepiting bakau dengan ukuran lebar karapas diatas $15 \mathrm{~cm}$ atau berat diatas 200 gram per ekor yang boleh ditangkap.

\subsection{Keterkaitan Antara Kelimpahan Kepiting Bakau Dengan Parameter Lingkungan}

Keterkaitan kelimpahan kepiting bakau dengan parameter perairan, dianalisis menggunakan Principal component analysis (PCA). Adapun parameter yang digunakan dalam analisis PCA yaitu kerapatan vegetasi mangrove, salinitas, derajat keasaman ( $\mathrm{pH}$ ), oksigen terlarut (DO), suhu, kerikil, pasir, lumpur, kelimpahan kepiting bakau. Adapun hasil yang didapatkan disajikan pada Gambar 9. Berdasarkan hasil Principal component analysis (PCA) pada Gambar 9 stasiun satu dicirikan oleh substrat berlumpur dan kerapatan vegetasi mangrove yang tinggi. Menurut Maulana et al. (2014), substrat berlumpur sangat mendukung pertumbuhan mangrove. Kondisi substrat tersebut bermanfaat baik untuk vegetasi maupun biota yang berada disekitarnya, sedangkan pada stasiun dua dicirikan oleh substrat kerikil. Pada stasiun tiga, kelimpahan kepiting bakau berkaitan dengan parameter perairan yaitu $\mathrm{pH}$ dan salinitas. Menurut Hastuti et al. (2016), nilai pH yang baik untuk pertumbuhan kepiting bakau berkisaran 7,0-9,0, menurut Sitaba et al. (2017), salinitas yang dibutuhkan kepiting bakau untuk hidup dan bertumbuh antara 10 ppt sampai 30 ppt. 


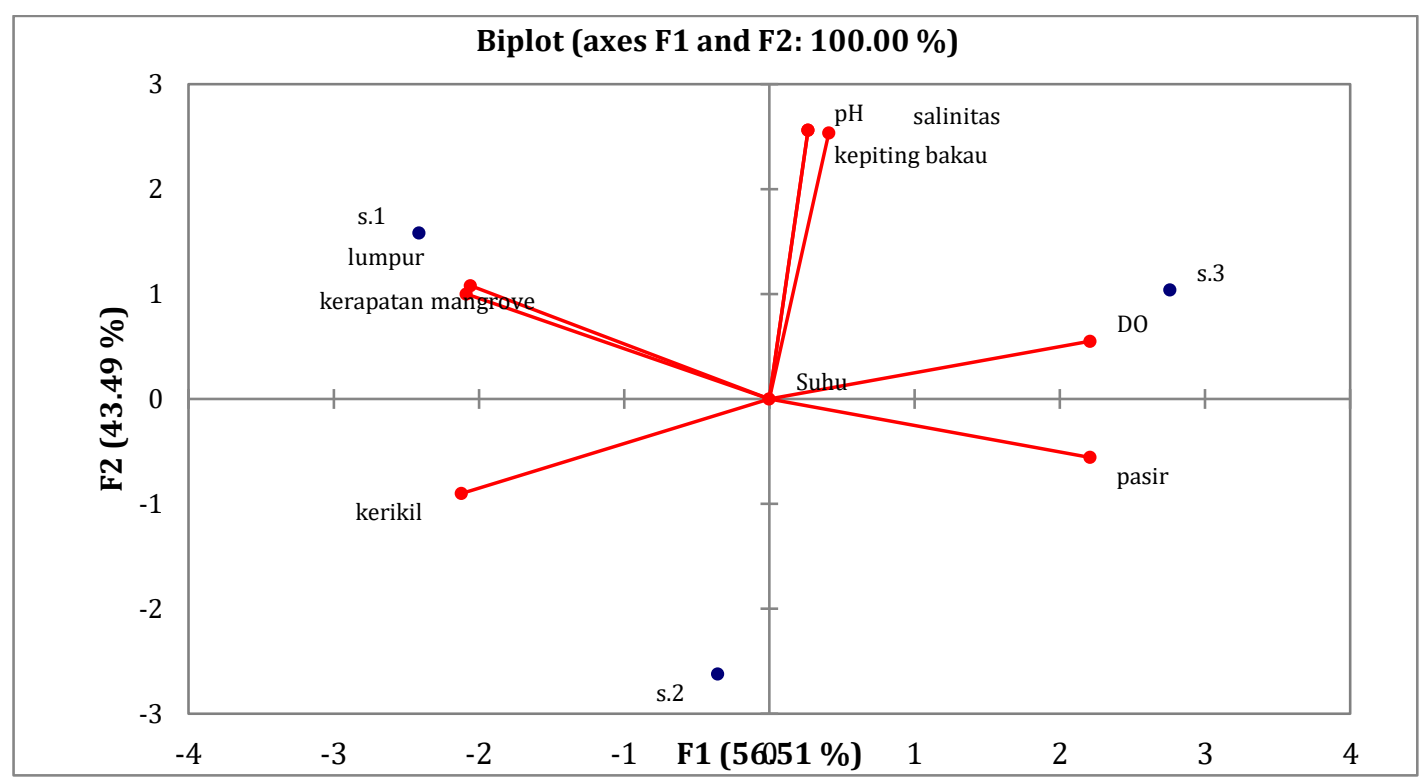

Gambar 9. Hasil Principal Component Analysis (PCA)

\subsection{Sebaran Kepiting Terhadap Kerapatan Mangrove}

Analisis korespondensi dilakukan untuk mengetahui sejauh mana sebaran kepiting terhadap kerapatan jenis mangrove di Desa Busung disajikan pada Gambar 10. Berdasarkan hasil Corespondence Analysis (CA) pada Gambar 10 menunjukkan pada sumbu Fl memiliki nilai kontribusi sebesar 99,1l\% dan pada sumbu F2 sebesar 0,89\%. Pada stasiun satu dicirikan dengan kerapatan vegetasi mangrove paling banyak ditemui yaitu spesies Xylocarpus granatum. Stasiun 3 dicirikan oleh keberadaan kepiting bakau spesies Scylla paramosain yang keberadaanya sangat keterkaitan dengan mangrove jenis Rhizophorra apiculata. Keberadaan vegetasi mangrove sangat mendukung keberlangsungan hidup kepiting bakau (Cahyaningrum et al., 2014).

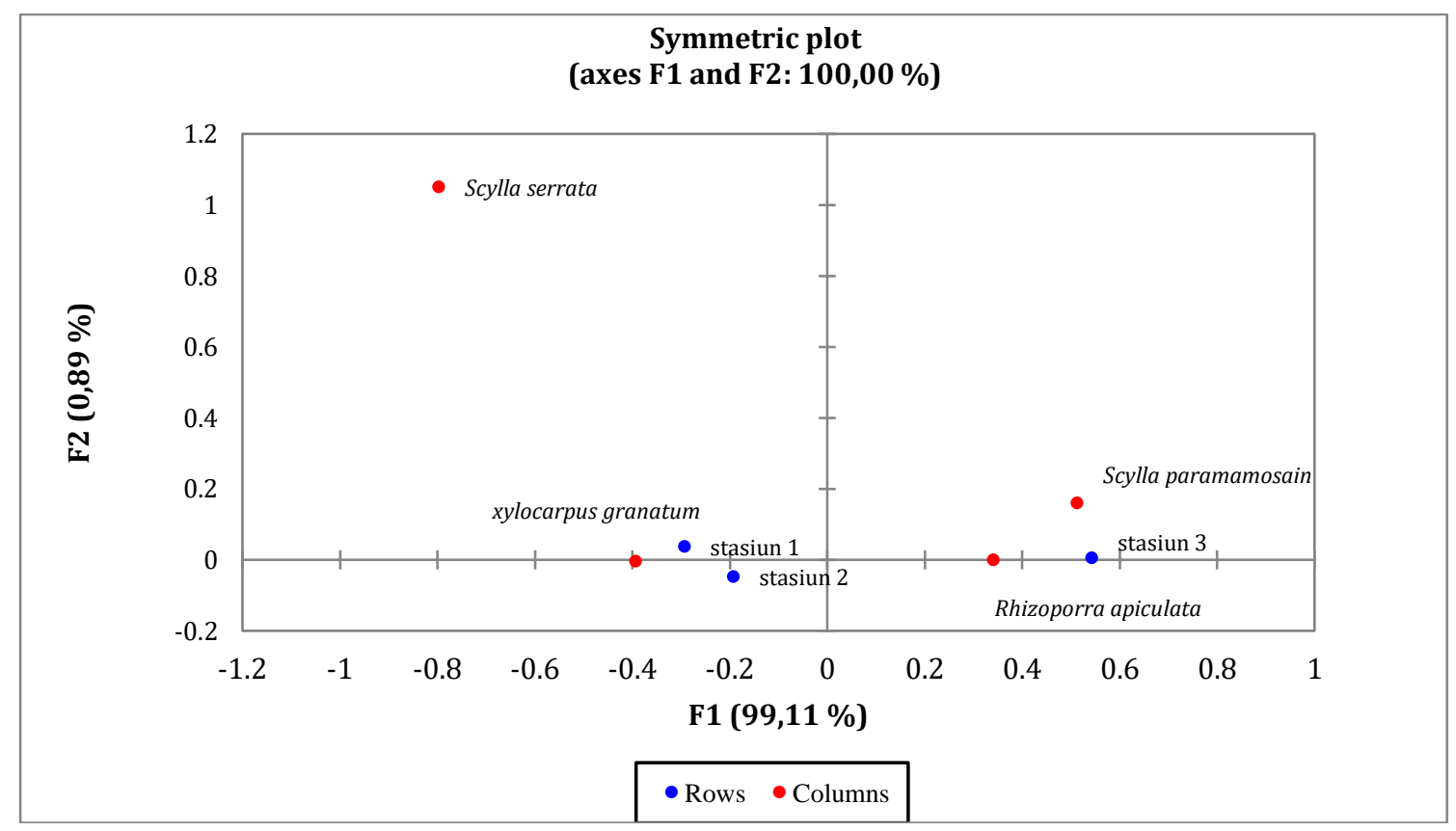

Gambar 10. Hasli Analisis Korespondesi Sebaran Kepiting Terhadap Kerapatan Mangrove

\section{SIMPULAN}

Kelimpahan dan karakteristik kepiting bakau yang ditemukan pada ekosistem mangrove di Desa Busung adalah jenis Scylla serrata dan Scylla paramamosain. Kelimpahan yang paling banyak ditemui dari lokasi penelitian yaitu jenis kepiting bakau Scylla paramamosain pada lokasi stasiun tiga atau lebih tepatnya di pesisir pemukiman masyarakat, dengan kerapatan total keseluruhan vegetasi mangrove yang paling banyak ditemui jenis Rhizopora apiculata. 


\section{REFERENSI}

Avianto, I., Sulistiono, \& Setyobudiandi, I. (2013). Karakteristik habitat dan potensi kepiting bakau Scylla serrata S.transquaberica dan S.olivacea di hutan mangrove cibako Kabupaten Garut Jawa Barat. Jurnal Bonorowo. 3(2): 55-72.

Bengen, D.,G. (2012). Analisis kuantitatif biofisik kelautan. Bogor (ID): Insitu Pertanian Bogor.

Buwono, Y.R.( 2017). Identifikasi dan kerapatan ekosistem mangrove di kawasan Teluk Pangpang Kabupaten Banyuwangi. Jurnal Ilmu Perikanan. 8(1): 32-37.

Cahyaningrum, S.T., Hartoko, A., \& Suryanti. (2014). Biomassa karbon mangrove pada kawasan mangrove pulau Kemujan Taman Nasional Karimunjawa. Journal Of Maquares. 3(3): 34-42.

Chadijah, A., Wadritno, Y., \& Sulistiono. (2013). Keterkaitan mangrove kepiting bakau Scylla olivacea dan beberapa parameter kualitas air di perairan pesisir Sinjai Timur. Jurnal Octopus. 1(2): 116-122.

Fitriah, E., Maryuningsih, Y., Chandra, E., \& Mulyani, A. (2013). Studi analisis pengelolaan hutan mangrove Kabupaten Cirebon. Jurnal Scientiae Educatia. 2(2): 1-18.

Hadi, A.M., Irawati, M.H., \& Suhadi. (2016). Karakteristik morfo-anatomi struktur vegetatif spesies Rhizopora apiculata Rhizoporaceae. Jurnal Pendidikan. 1(9): 1688-1692.

Hamuna, B., Tanjung, R.H.R., Suwito, Maury, H.K., \& Alianto. (2018). Kajian Kualitas Air Laut dan Indeks Pencemaran Berdasarkan Parameter Fisika-Kimia di perairan Distrik Depapre Jayapura. Jurnal Ilmu Lingkungan. 16(1): 35-43.

Hastuti, Y.P., Affandi, R., Millaty, R., Nurussalam, W., \& Tridesianti, S. (2019). Suhu terbaik untuk meningkatkan pertumbuhan dan kelangsungan hidup benih kepiting bakau Scylla serrata di sistem resirkulas. Jurnal Ilmu dan Teknologi Kelautan Tropis. 11(2): 311322.

Hastuti, Y.P., Nadeak, H., Affandi, R., \& Faturrohman, K. (2016). Penentuan pH optimum untuk pertumbuhan kepiting bakau Scylla serrata dalam wadah terkontrol. Jurnal Akuakultur Indonesia. 15(2): 171-179.

Hardiyanti, A.S., Sunaryo, Riniatsih, I., \&ESantoso, A., (2018). Biomorfometrik kepiting bakau Scylla Sp. hasil tangkapan di perairan Semarang. Jurnal Buletin Oseanografi Marina. 7(2): 81-90.

Irwani, \& Suryono, C.A. (2012). Pertumbuhan kepiting bakau Scylla serrata di kawasan mangove. Jurnal Buletin Oseanografi Marina. $1(1): 15-19$

Julaikha, S., \& Sumiyati, L. (2017). Nilai ekologis hutan ekosistem hutan mangrove. Jurnal Biologi Tropis. 17(1): 23-31.

KEPMENLH. (2004). Keputusan menteri negara lingkungan hidup. Kriteria baku dan pedoman penentuan kerusakan mangrove. Menteri negara lingkungan hidup. Hoetomo. Jakarta.

KKP. (2016). Kepala badan karantina ikan pengendalian mutu dan keamanan hasil perikanan. Pedoman pemeriksaan atau identifikasi jenis ikan dilarang terbatas kepiting bakau. Kementrian Kelautan dan Perikanan. Jakarta.

Maulana, F., Hendrarto, B., \& Suryanti. (2014). Karakteristik ukuran tinggi dan diameter batang seedling rhizophora mucronata pada substrat dengan kandungan lumpur yang berbeda di Pulau Pahawang Kabupaten Pesawaran Lampung. Journal OfMaquares. 3(3): 130-133.

Pambudi, D.S., Budiharjo, A., \& Sunarto. (2019). Kelimpahan dan keanekaragaman kepiting bakau Scylla spp di kawasan hutan bakau pasar Banggi Rembang. Jurnal Penelitian Perikanan Indonesia. 25(2): 93-102.

Patty, S.I. (2013). Distribusi suhu salinitas dan oksigen terlarut di perairan Kema Sulawesi Utara. Jurnal Ilmiah Platax. 1(3): 148-157.

Putra, D., Sarong, M.A., \& Purnawan, S. (2016). Kelimpahan kepiting bakau Scylla di kawasan rehabilitasi mangrove Pulo Sarok Kecamatan Singkil Kabupaten Aceh Singkil. Jurnal Ilmiah Mahasiswa Kelautan dan Perikanan Unsyiah. 1(2): 229-235.

Safitri, S.F., Sunaryo, \& Djunaedi, A. (2020). Biomorfometri kepiting bakau di perairan Bandengan Kendal. Jurnal Marine Research. 9(1): 55-64.

Saputri, M., \& Muammar. (2018). Karakteristik habitat kepiting bakau Scylla sp di ekosistem mangrove Silang Cadek Kecamatan Baitussalam Kabupaten Aceh Besar Provinsi Aceh. Jurnal Biotik. 6(1): 75-80.

Sara, L. (2010). Study on the size structure and population parameters on mud crab Scylla serrate in lawele bay southeast Sulawesi Indonesia. Journal Coas Dev. 13(2): 133-147.

Schaduw, J.N.W. (2015). Bioekologi mangrove daerah perlindungan laut bebasis masyarakat Desa Blongko Kecamatan Sinonsayang Kabupaten Minahasa Selatan Provinsi Sulawesi Utara. Jurnal LPPM Bidang Sains dan Teknologi. 2(1): 89-102.

Sentosa, A.A., \& Syam, A.R. (2011). Sebaran temporal faktor kondisi kepiting bakau Scylla serrata di perairan pantai Mayangan Kabupaten Subang Jawa Barat. Jurnal Perikanan. 13(1): 35-43.

Setiawan, H. (2013). Status ekologi hutan mangrove pada berbagai tingkatan. Jurnal Penelitian Kehutanan Wallacea. 2(2): 104-120.

Setiyawan, F. (2015). Kesesuaian kawasan pesisir Desa Busung sebagai kawasan wisata pantai di Kecamatan Seri Kuala Lobam Kabupaten Bintan. Universitas Maritim Raja Ali Haji. Tanjung Pinang.

Siringoringo, Y.N, Desrita, \& Yunasfi. (2017). Kelimpahan dan pola pertumbuhan kepiting bakau Scylla serata di hutan mangrove Kelurahan Belawan Sicanang Kecamatan Medan Belawan Provinsi Sumatera Utara. Jurnal Acta Aquatica. 4(1): 26-52.

Sofarini, D. (2012). Keberadaan dan kelimpahan fitoplankton sebagai salah satu indikator kesuburan lingkungan perairan di Waduk Riam Kana. Journal Enviro Scienteace. 8(1): 30-34.

Sitaba, R.D., Salindeho, I.R.N, \& Kusen, D.J. (2017). Pengaruh perbedaan salinitas terhadap pertumbuhan kepiting bakau Scylla serrat. Jurnal Budidaya Perairan. 5(2): 8-14.

Sunarto, Sulistiono, \& Setyobudiandi, I. (2015). Hubungan jenis kepiting bakau Scylla Spp dengan mangrove dan substrat di tambak Silvofishery Eretan Indramayu. Journal Marine Fisheries. 6(1): 59-68.

Suryana, E., Elvyra, R., \& Yusfiati. (2015). Karakteristik morfometrik dan meristik ikan lais kryptopterus limpok bleeker 1852 di Sungai Tapung dan Sungai Kampar Kiri Provinsi Riau. Jurnal Fmipa. 2(1): 67-77.

Syahrera, B., Purnama, D., \& Ta’alidin, Z. (2016). Asosiasi kelimpahan kepiting bakau dengan keberadaan jenis vegetasi mangrove Kelurahan Sumber Jaya Kecamatan Kampung Melayu Kota Bengkulu. Jurnal Enggano. 1(2): 47-55.

Tahmid, M. (2016). Kajian ekologi ekonomi kepiting bakau Scylla serrata forskal 1775 di ekosistem mangrove Teluk Bintan Kabupaten Bintan. Insitutu Pertanian Bogor. Bogor.

Umroh. (2015). Penyemaian dan penanaman Rhizophora apiculata di daerah pasca penambangan timah inkonvensional Ti di Muara Kudai Kabupaten Bangka. Jurnal Kelautan. 8(1): 19-25. 
Unthari, D.T, Purwiyanto, A.I, \& Agussalim, A. (2018). Hubungan kerapatan mangrove terhadap kelimpahan kepiting bakau Scylla sp dengan penggunaan bubu lipat sebagai alat tangkap di Sungai Bungin Kabupaten Banyuasin Provinsi Sumatera Selatan. Jurnal Maspari. 10(1): 41-50.

Wijaya, N.I., Yulianda, F., Boer, M., \& Juwana, S. (2010). Biologi populasi kepiting bakau Scylla serrata di habitat mangrove Taman Nasional Kutai Kabupaten Kutai Timur. Jurnal Oseanografidan Limologi Indonesia. 1(3): 443-461.

Zakaria, M., \& Rajpar, M.N. (2015). Assessing the fauna diversity of marudu bay mangrove forest Sabah Malaysia for future conservation. Diversity. 7(1): 137-148. 